\title{
The Hawaiian Island Environment
}

\author{
Ayn Shlisky
}

$\mathrm{P}$

aradise: the universal vision we have of Hawai 'i. Hawai 'i's habitats are diverse, unique, and lovely - a land of flowing red-hot lava, and at the same time, delicate pastel orchids. Yet the Hawai' $i$ of today is much changed from that discovered by the Polynesians, or more than 1,000 years later, by Captain Cook. Over time, Hawai' $i$ has been discovered and re-discovered by different groups of people of widely varied goals and aspirations. Partly because of this, the introduction of exotic species, an important concern to range managers worldwide, is one major challenge to rangeland and ecosystem management and conservation in Hawai 'i.

\section{The Hawaiian Ecosystem}

Geologic evolution, tropical climate, and island isolation underlie the diversity and distribution of island vegetation (Hubbell 1968, Sohmer and Gustafson 1987). The eight islands considered within the State of Hawai' $i$ are those between $19^{\circ} \mathrm{N}$ to $22^{\circ} \mathrm{N}$ latitude, although the entire Hawaiian Island chain follows a 1,600 mile arc from $9^{\circ} \mathrm{N}$ to $28^{\circ} \mathrm{N}$ latitude. Some islands rise to more than $32,000 \mathrm{ft}$, but the oldest island of the chain is low-lying Kure Atoll to the northwest, and the youngest, Loihi, is still below sea level, to the southeast.

Island ages range from over $75 \mathrm{mil}-$ lion years to less than 500,000 years (Clague and Dalrymple 1989, Walker 1990). Erosion increases from east to west with island age, as evidenced by the contrast between deeply incised Waimea Canyon on Kaua' $i$, and the slightly eroded lava beds of Mauna Loa and Mauna Kea on Hawai 'i. This progressive aging has been largely attributed to the hypothesis, first proposed by Wilson (1963), that the Hawaiian Islands are formed by the movement of the sea floor (Pacific plate) over sources of lava called "the Hawaiian hot spot".
Each island is the result of accumulations of successive volcanic eruptions at the Hawaiian hot spot. The older volcanoes have been transported from the Hawaiian hot spot to the northwest by plate movement. Through time, they erode and subside to become a mere pinnacle of rock, then an atoll of accumulated coral, and finally a submerged guyot (flat, reef-capped volcano) (Normark et al. 1982). Only volcanoes of Hawai' $i$ and Loihi are still active.

Nowhere else in the United States are rainfall gradients so steep. Annual rainfall averages 70 inches, but ranges from 5 to 470 (Blumenstock and Price 1972, $\mathrm{McNab}$ and Avers 1994). The highest annual rainfall is on the eastern, windward sides or crests of mountains, where almost year-round trade winds shed
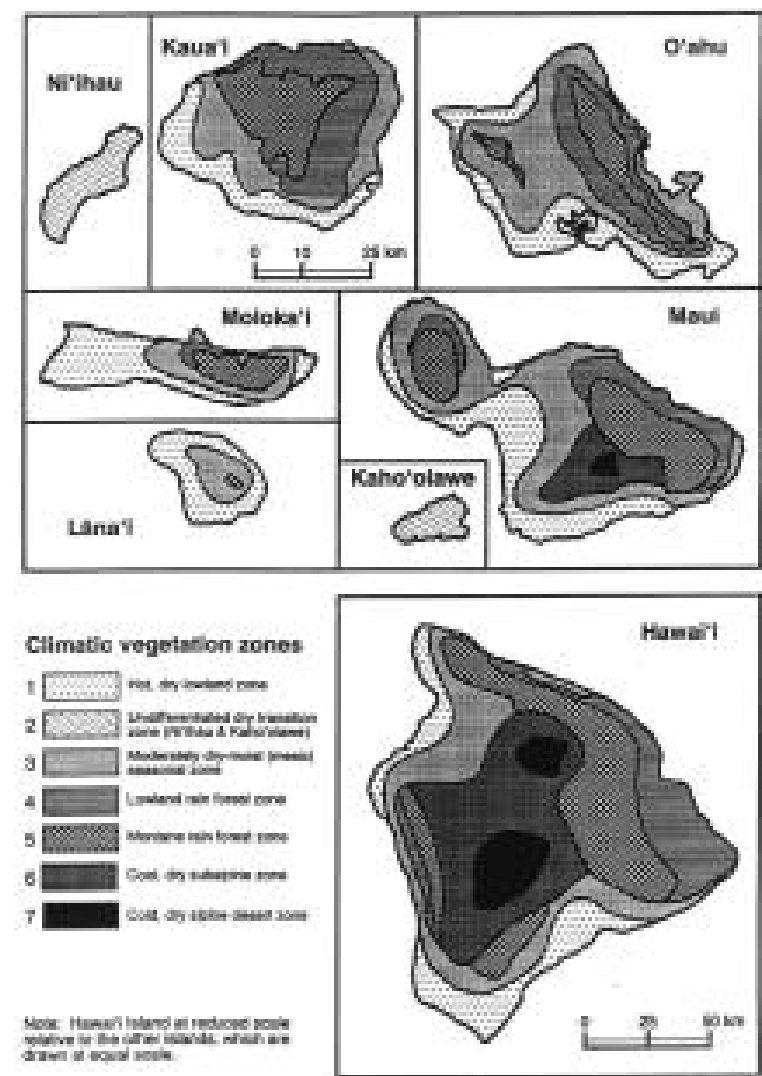

most of their moisture. The driest areas are the upper slopes of high mountains, where a trade wind inversion tends to suppress vertical lifting of air, or in leeward positions at the coast or inland. Winter cold fronts moving in from the northwest may infrequently travel far enough south to drop snow on the upper slopes of Haleakala (Maui), Mauna Loa and Mauna Kea (Hawai' $\mathrm{i}$ ).

Geographic isolation is another important factor influencing Hawaiian plant and ecosystem diversity. The nearest continent, North America, is 2,300 miles away, while Japan, Australia and the Philippines are 2,500, 4,000 and 5,300 miles away, respectively. Never linked geographically with continental land (Carlquist 1982), the isolation of Hawai' $i$ dictates that, before human ar-
Fig. 1. Climatic vegetation zones of the eight main Hawaiian Islands (from Mueller Dombois and Fosbert 1998 with permis sion from Springer-Verlag). 
rival, only species capable of long-distance dispersal, and pre-adapted to tropical climates, could become established. Major agents of dispersal for Hawaiian plant species are migratory birds (Carlquist 1982), led to the islands by chance or storm movements. Air and water currents also disperse plants, but are less important due to distance and the amount of non-coastal habitat in Hawai 'i. The largest proportion of native plants are related to plants in tropical Asia and Indonesia, and more than 20 percent to plants of North and South America (Carlquist 1982).

Once established, isolation and high habitat diversity favors speciation, as evidenced by the high degree of endemism in the Hawaiian Islands. The Islands contain 960 flowering plants and 168 ferns and fern allies (Wagner et al. 1990). Endemism within the Islands is estimated to be between 86 and 96 percent (Mueller-Dombois 1975, MuellerDombois and Fosberg 1998). Conversely, the small size of island land masses supports small populations, increasing extinction rates (MacArthur and Wilson 1967), and reducing resilience to disturbance (Loope and Mueller-Dombois 1989).

\section{Plant Communities}

Humans have altered the Hawaiian landscape. Nonetheless, island habitats remain highly diverse, and so are the plant communities that occupy them (Figure 1). The Hawai'i Natural Heritage Program recognizes 150 distinct natural community types, including aquatic and subterranean types like caves. Most communities can be classified into nine broad types: tropical coastal vegetation, lowland grasslands and savanna, montane moist forests, lowland rain forest, montane wet forests and bogs, subalpine vegetation, alpine vegetation, and montane dry forests (McNab and Avers 1994).

Coasts are rimmed by coral sand beaches and associated strand vegetation (Figure 2). Leeward slopes, mostly below $1500 \mathrm{~m}$, are dry, and were formerly covered by dry grassland, or open forest/woodland of predominantly broad schlerophyll trees, such as Metrosideros polymorpha (locally known as 'ohi' a

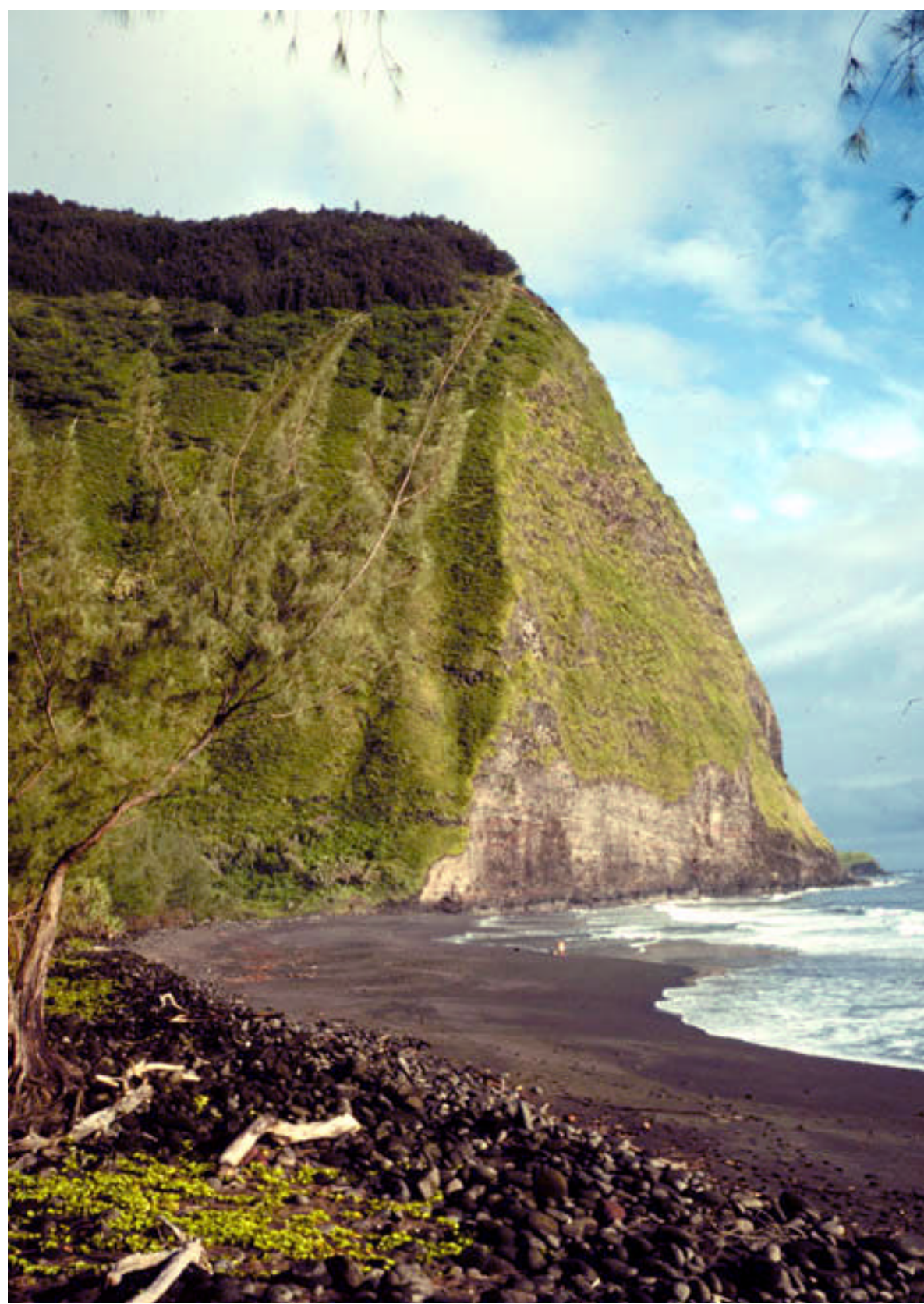

Fig. 2. Waipo Valley, Hawai'i, on the northeastern coast. Courtesy of Paul F. Starrs.

lehua) or Diospyros sandwicensis (Figure 1, zones 1 and 2). Hawai'i's northwestern side at Pu'u Wa' a Wa'a contains a notable remnant of this type (Mueller-Dombois and Fosberg 1998). Between the dry leeward and wet windward climates, montane moist forests once dominated, but today most of this type has been converted to other uses (Figure 1, zone 3 ). This type is either dominated by lehua, the Polynesian-introduced kukui nut tree (Aleurites moluc cana), or a mix of lehua and the non-native Myrica faya, or Acacia koa (koa).
Native lowland rain forests occupy windward low elevations, and are dominated by open forests of lehua (Figure 1, zone 4). Much has also been converted to other uses (e.g., development, agriculture), and like other vegetation types in Hawai' $i$, has been invaded by introduced species, including Casuarina equisetifolia and Paraserianthes falcataria. These lowland rainforests include the conspicuous stoloniferous fern mats of the native false staghorn fern (Dicranopteris linearis), which usually indicate either advanced primary succes- 
sion, or a breakdown stage of lehua forest (Mueller-Dombois and Fosberg 1998). Above these lowland rainforests lie tropical montane cloud forests, which as their name suggests, are enveloped with clouds at least part of the day. Similar to lowland rainforests, they are dominated by lehua in addition to Cheirodendron trigynum, although they differ in that they receive a large amount of additional precipitation as fog drip, contributing to their mossy character. Montane bogs mostly occur as rain forest openings, and are dominated by a mixture of sedges and grasses. Above $5,900 \mathrm{ft}$ in the high elevations of Hawai' $i$ and Maui, where conditions are relatively dry, and snow sometimes falls (Figure 1, zones 6 and 7), are found subalpine and alpine vegetation; either mountain parkland, schlerophyll scrub, Chenopodium scrub, or tussock grassland. Despite elevation and ruggedness, historic overgrazing by feral and domestic sheep and goats has contributed to exotic plant invasions and drastic composition changes (Mueller-Dombois and Fosberg 1998).

Island age, because it is linked to soil properties and topographical relief, in part determines the suite of species established on any particular island. There is a correlation between substrate age and soil moisture regime in mid-elevation rain forests, where soil water regimes tend to change from xeric to hydromorphic through time (MuellerDombois 1975). Tied to generally increasing soil moisture regimes from the younger island of Hawai' $i$ toward the older island of Oahu is a decrease in range of the common forest tree lehua. Dieback of lehua on wet sites on the islands of Maui and Hawai ' $i$ have been attributed in part to this species' inability to adapt to aging soils (MuellerDombois and Fosberg 1998). Island age also determines its relative degree of erosion and its unique topography. For example, species such as Cryptocarya mannii and Elaeocarpus bifidus occur only in the mixed mesophytic forests on Kaua' $i$ and Oahu (Sohmer and Gustafson 1987).

The past 200 years have witnessed drastic changes to native Hawaiian ecosystems. On the heels of European contact in the late $18^{\text {th }}$ century, the intro-

duction of large grazing and browsing mammals (some of which have become destructive feral populations), the exploitation of lowland forests for sandalwood (Santalum spp.), land clearing for agriculture (especially sugarcane) and development, koa logging, and the conversion of upland forests into cattle ranches (Cuddihy and Stone 1994, Mueller-Dombois and Fosberg 1998) have left few island ecosystems in their native state. The introduction of non-native plant species and the extinction of many native and endemic species have been two of the most significant results of these activities.

Of course a detailed account of all of the ecological issues facing Hawai ' $i$ today cannot be covered here, but introduced plant species and feral pigs are two of particular concern to range managers and scientists.

..overgrazing by large feral populations of grazing animals in the late $18^{\text {th }}$ century caused invasion by non-native shrub species...

\section{Exotic Species}

Many ecological relationships on islands involve the interaction between native and exotic species. Greater than 8,000 plant species have been introduced (Yee and Gagne 1992), mostly within the last 200 years (MuellerDombois 1975). Of these, about 11 percent now have reproducing populations (Wagner et al. 1990), and at least 86 of these species pose threats to native ecosystems (Smith 1985). Smith (1985) lists 13 species, five of which are grasses, as some of the worst weeds, including Myrica faya, Psidium cattleianum, Andropogon virginicus, Schizachyrium condensatum, Melinis minutiflora, Pennisetum clandestinum, and P. se taceum. Some are so competitive that they can convert native forest to singlespecies stands, particularly after disturbances such as a hurricane or 'ohi' a lehua dieback. Others can alter natural processes such as nutrient cycling, sometimes facilitating the invasion of other non-native species (Vitousek 1986, Vitousek and Walker 1989).

In dry and mesic vegetation, alien grass establishment has increased fire frequency to a degree deleterious to native plants (Cuddihy and Stone 1994). The eastern North American grass Andropogon virginicus has spread across denuded lowland rain forest habitats on windward Oahu, now forming the dominant herbaceous cover. In addition to displacement of native species, this fire-adapted bunchgrass accumulates dead standing foliage, within a few years forming a straw-like mulch that prevents evapotranspiration from the soil surface during winter months when excess water is a problem (MuellerDombois 1975). Consequently, this habitat now shows more erosion and runoff than forested sites where evapotranspiration is considerably greater. In dry forest on the leeward slopes of Maui, African kikuyu grass (Pennisetum clandestinum) was introduced by ranchers for its forage value. The thick matforming habit of this grass inhibits native tree regeneration. On Oahu, overgrazing by large feral populations of grazing animals in the late $18^{\text {th }}$ century caused invasion by non-native shrub species, such as Prosopsis pallida, Acacia farnesiana, Lantana camara, and Opuntia ficus-indica, which today make up their own community types within the dry lowlands (MuellerDombois and Fosberg 1998).

During the 1960's through 1980s, the montane moist forest once dominated by open lehua was invaded by Myrica faya from the Macronesian Islands. Myrica faya is a nitrogen-fixing tree, and its invasion not only increases forest density, but also causes nitrogen accumulation. The nitrogen is used by the Myrica trees themselves, allowing them to displace at least partially, lehua (Walker and Vitousek 1991). Effects of exotic species, in addition to community type and land use changes, contribute to ongoing species extinctions, with nearly a quarter of native plants proposed or listed as threatened or endangered (McNab and Avers 1994).

\section{Feral Pigs}

European feral pigs have had substantial effects on Hawaiian rain forests and 
other ecosystems. In addition to eating common foods such as tree-fern trunks, strawberry guava fruits (Psidium cat tleianum), and earthworms, pigs seek out certain now rare plant species for food (Loope 1998). Plants with fragile stems and leaves have drastically declined. Pigs also are dispersal agents for non-native plant species. They carry seed on their coats or in their digestive tracts, depositing it on the exposed mineral soil of the forest floor where germination is favored, often resulting in understory thickets of strawberry guava (Loope 1998, Mueller-Dombois and Fosberg 1998).

The isolation, tropical location, and beauty of the Hawaiian Islands have resulted in their uniqueness, but also contributed to their degradation. Few remnants of natural vegetation are left in the coastal and lowland areas, where resorts follow the ocean beaches, and agriculture or ranching claims arable and grazable lands. More than 75 percent of the recognized plant community types remaining in these areas are considered rare (Cuddihy and Stone 1994). Though less disturbed, montane and subalpine areas have not escaped the effects of development and non-native plant species invasions. Areas still covered with native vegetation can be found in forest reserves, the State Natural Area Reserve System, a State Wilderness Preserve, the National Park, and Nature Conservancy Preserves. While The Nature Conservancy continues to identify lands that contain unprotected ecosystem types, it will take a coordinated effort of increased preservation of unprotected sites, conservation of existing native ecosystems, restoration of degraded sites, and recovery of threatened and endangered species to ensure that Hawai'i's unique ecosystems and natural processes are not lost forever.

\section{References}

Blumenstock, D. I., and Price, S. 1972. Climates of the states: Hawai 'i. In: E. A. Kay, (ed.) A Natural History of the Hawaiian Islands. Selected Readings., University of Hawai 'i, Honolulu, pp. 155-204.

Carlquist, S. 1982. The first arrivals. Natural History 91:20-30.
Clague, D. A., and Dalrymple, G. B. 1989. Techtonics, geochronology, and origin of the Hawaiian-Emporer Volcanic chain. In: E. L. Winterer, D. M. Hussong and R. W. Decker (eds.) The Eastern Pacific Ocean and Hawai'i., The Geological Society of America, Boulder, Colo., pp. 188-217.

Cuddihy, L. W., and Stone, C. P. 1994. Summary of vegetation aleration in the Hawaiian Islands. In: E. A. Kay (ed.) A Natural History of the Hawaiian Islands: Selected Readings II. University of

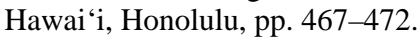

Hubbell, T. H. 1968. The biology of islands. Proceedings of the National Academy of Sciences 60:22-32.

Loope, L. L. 1998. Hawai' $i$ and the Pacific Islands Status and Trends of the Nation's Biological Resources, United States Geological Survey, Washington, D. C.

Loope, L. L., and Mueller-Dombois, D. 1989. Characteristics of invaded islands, with special reference to Hawai'i. In: J. Drake, F. di Castri, R. Groves, F. Kruger, H. A. Mooney, R. Rejmanek and M. Williamson (eds.) Biological invasions: A global perspective., John Wiley and Sons, New York, pp. 257-280.

MacArthur, R. H., and Wilson, E. O. 1967. The Theory of Island Biogeography Princeton University Press, Princeton.

McNab, W. H., and Avers, P. E. 1994. Ecological Subregions of the United States: Section Descriptions. U. S. Department of Agriculture, Forest Service, Administrative Publication WO-WSA-5.

Mueller-Dombois, D. 1975. Some aspects of Island ecosystem analysis. In: F. B. Golley and E. Medina (eds.) Tropical Ecological Systems: Trends in Aquatic and Terrestrial Research, Springer-Verlag, New York, pp. 353-366.

Mueller-Dombois, D., and Fosberg, F. R. 1998. Vegetation of the Tropical Pacific Islands, Volume 132. M. M. Caldwell, G. Heldmaier, O. L. Lange, H. A. Mooney, E.-D. Schulze and U. Sommer (eds.) Springer-Verlag, New York.

Normark, W. R., Clague, D. A., and Moore, J. G. 1982. The next island. Natural History 91:68-71.

Smith, C. W. 1985. Impacts of alien plants on Hawai'i's native biota. In: C. P. Stone and J. M. Scott (eds.) Hawai'i's terrestrial ecosystems: preservation and management, University of Hawai 'i Cooperative National Park Resources Unit, Honolulu, pp. 180-250.

Sohmer, S. H., and Gustafson, R. 1987. Plants and Flowers of Hawai'i. University of Hawai' 'i Press, Honolulu.

Vitousek, P. M. 1986. Biological invasions and ecosystem properties: can species make a difference? In: H. A. Mooney and J. Drake (eds.) The Ecology of Biological Invasions of North America and Hawai ' $i$, Springer-Verlag, New York, pp. 163-176.
Vitousek, P. M., and Walker, L. R. 1989. Biological invasion by Myrica faya in Hawai'i: plant demography, nitrogen fixation, ecoosystem effects. Ecol. Mono. 59:247-265.

Wagner, W. L., Herbst, D. R., and Sohmer, S. H. 1990. Manual of the flowering plants of Hawai 'i. Bishop Museum and University of Hawai' $i$, Honolulu.

Walker, G. P. L. 1990. Geology and volcanology of the Hawaiian Islands. Pacific Science 44:315-347.

Walker, L. R., and Vitousek, P. M. 1991. Interactions of an alien and a native tree during primary succession in Hawai ' $i$ Volcanoes National Park. Ecology 72:1449-1455.

Wilson, J. T. 1963. A possible origin of the Hawaiian Islands. Can. J. Physics 41:863-870.

Yee, R. S. N., and Gagne, W. C. 1992. Activities and needs of the horticulture industry in relation to alien plant problems in Hawai'i. In: C. P. Stone, C. W. Smith and J. T. Tunison (eds.) Alien plant invasions in native ecosystems of Hawai ' $\mathrm{i}$ : management and research. University of Hawai'i Cooperative National Park Resources Studies Unit, Honolulu, pp. 712-725.

Author is Graduate Student Researcher, University of California, Berkeley, 151 Hilgard Hall MC 3110, Berkeley, CA 94720 